\title{
A simplified algorithm for calculating benthic nutrient fluxes in river systems
}

\author{
Gilles Billen $^{1 *}$, Josette Garnier ${ }^{1}$ and Marie Silvestre ${ }^{2}$ \\ 1 UMR Sisyphe, UPMC/CNRS, 4 place Jussieu, 75005 Paris, France \\ ${ }^{2}$ FR FIRE, UPMC/CNRS, 4 place Jussieu, 75005 Paris, France
}

Received 19 October 2013; Accepted 24 September 2014

\begin{abstract}
Benthic organic matter microbial oxidation is the basic process by which oxidants such as oxygen, nitrate and sulphate are consumed in sediments, while ammonium and phosphate are released. Although these processes play a crucial role in river biogeochemistry, their modelling remains a difficult challenge. Thouvenot et al. [J. Hydrol., 341, 55-78, 2007; 379, 239-250, 2009] have proposed a model of the processes involved in organic matter degradation in a vertical gradient of oxic to anoxic conditions, considering one upper fluid, erodable sediment layer, with transient behaviour, overlaying a compacted sediment layer assumed to be at steady state. In this paper, we present a thorough analysis of the response of Thouvenot's model to the various constraints affecting benthic processes, according to a conceptual interpretative framework relating the nutrient fluxes across the sediment-water interface to the depth-integrated value of certain sediment properties, such as their oxidant demand and their total ammonification rate. Based on this analysis, we propose a new alternative algorithm simplifying the calculation of the benthic fluxes. This algorithm is designed to be suitable for inclusion in any model of in-stream biogeochemical processes.
\end{abstract}

Key words: Benthic processes / nutrient cycling / river systems / modelling

\section{Introduction}

In aquatic systems, including river systems, the benthic boundary layer (Lorke and MacIntyre, 2009) represents a hot spot of biological and biogeochemical processes. Benthic fluxes indeed play a significant role of transformation, retention and elimination of nutrients from the water column (Garnier and Billen, 1993; Seitzinger et al., 2002). In shallow, small order rivers, the benthic compartment, in addition to being the site of deposited sediment reworking, might also be defined as the hyporheic zone, i.e., the area where stream water mixes with shallow groundwater (Runkel et al., 2003). Hyporheic exchanges, or movement of surface water into and out of the streambed, increases the volume of stream water in contact with sediment biota, enhancing biologic reactions. These are particularly important in rivers flowing over gravel beds, where the interaction between biofilms and hyporheic flow (SánchezPérez et al., 2003; Weng et al., 2003; Flipo et al., 2004; Peyrard et al., 2011) plays a major role, besides the direct interaction of bottom sediments with the overlying river water. In most lowland rivers, however, as well as in lentic

\footnotetext{
*Corresponding author: gilles.billen@upmc.fr
}

systems, benthic processes are dominated by the diffusive exchange of solutes between the water column and a layer of freshly deposited, re-erodable and compacting sediments (Billen and Lancelot, 1988). High hyporheic advective fluxes, as reported by Sheibley et al. (2003), are rather exceptional in this context, but the stream flow, and its variations, are enhancing the exchanges between the freshly deposited particles and the water column. The properties of these sediments, in particular their content in biodegradable organic matter, are the main drivers of oxygen and nutrient exchanges across the water-sediment interface (Arndt et al., 2013).

Experimental approaches to benthic nutrient exchanges have been reviewed by Viollier et al. (2003); they include direct measurements using bell-jars (Billen et al., 1989; Garban et al., 1995) or measurements of gradients using cores, dialysis cells (Garban et al., 1995) or microelectrodes (Dedieu et al., 2007). Based on data from these types of measurement, a number of models of benthic fluxes have been proposed, relating the flux of sedimenting organic material to consumption of oxygen and production of nutrients in the benthos compartment. Soetaert et al. (2000) have reviewed the published approaches to couple benthic and water column biogeochemical models. 
a. Analytical diagenetic models (Berner,1980; Boudreau, 1997) Steady state diagenesis assumed

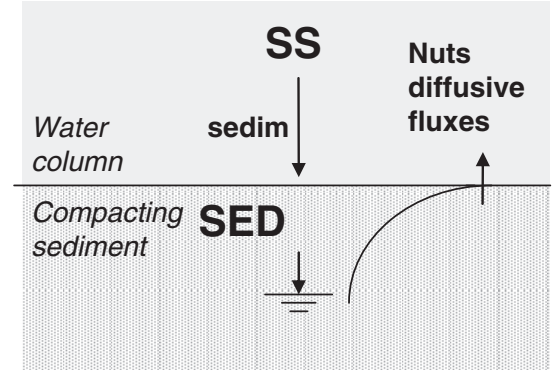

b. Multi-layer numerical approach (e.g.Soetaert et al., 1996)

Transient states considered

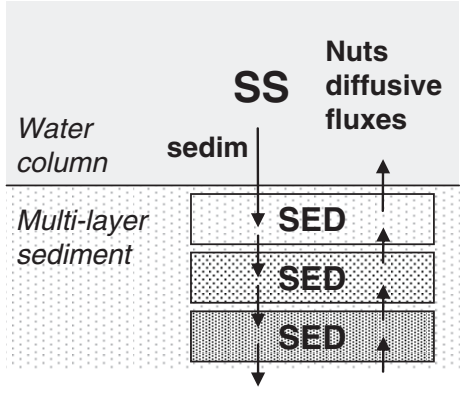

C. Two layers hybrid approach (Thouvenot et al., 2007, 2009) Transient state in the upper fluid layer Steady state in the lower layer

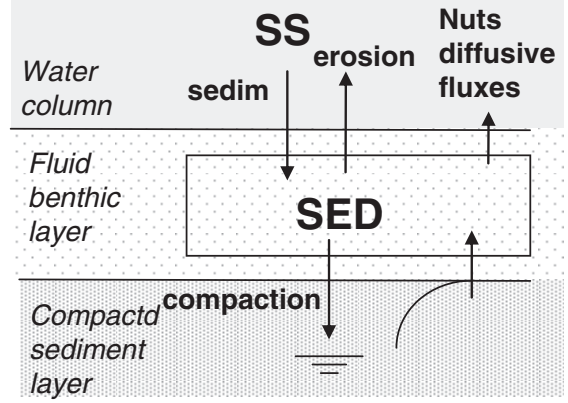

Fig. 1. A simplified typology of nutrient-benthic-nutrient remineralization models.

The first generation of models used to describe benthic processes are those developed by Berner and Aller in the 1980s and early 1990s, assuming steady-state conditions and analytically solving simple diagenetic equations (Vanderborght et al., 1977; Lerman, 1978; Berner, 1980; Westrich and Berner, 1984; Aller and Aller, 1992) (Fig. 1(a)). Other authors in the 1990s introduced numerical models considering vertically resolved discrete layers of sediments able to take into account the fine depth resolution of benthic processes as well as their transient nature (Rabouille and Gaillard, 1991; Boudreau, 1996, 1997; Soetaert et al., 1996; Testa et al., 2013) (Fig. 1(b)). When applied to rivers, this strategy leads to either oversimplified approaches with only one or two sediment layers for each river stretch (Even et al., 2007) or very high calculation costs. More recently, Thouvenot et al. (2007, 2009) have proposed a hybrid approach considering one upper fluid, erodable sediment layer, with transient behaviour, overlaying a compacted sediment layer assumed to be at steady state (Fig. 1(c)). The model is based on a detailed analysis of the processes involved in organic matter degradation in a vertical gradient of oxic to anoxic conditions. Contrary to the multi-layer approaches, the model makes the choice, for the lower compacted layer, of an analytical resolution of the diagenetic equations instead of numerical modelling. Thouvenot's model has been implemented in the current version of the Seneque/ Riverstrahler model describing biogeochemical processes in drainage networks (Ruelland et al., 2007; Thieu et al., 2009) and validated with direct measurements available in the Seine river system (Thouvenot et al., 2009).

However, the calculation scheme associated with this model, based on the analytical resolution of diagenetic equations, is numerically complex, because it requires solving implicit equations, making this benthic module of the Seneque/Riverstrahler model rather expensive in terms of calculation time. Moreover, this part of the calculation scheme has been found to be unstable in certain extreme modelling situations.

In this paper, we present a thorough analysis of the response of Thouvenot's model to the various constraints affecting benthic processes, primarily based on the concept of oxidant benthic demand, which we argue is the major driver of all benthic processes, as also discussed in detail by the recent review published by Arndt et al. (2013). Based on this analysis, we propose a new alternative algorithm simplifying the calculation of the benthic fluxes, while complying with the constraint of matter conservation. The algorithm is designed to be suitable for inclusion in any model of in-stream biogeochemical processes, including Seneque/Riverstrahler, but also other modelling approaches such as SWAT (Arnold et al., 1998, 1999).

\section{Experimental basis for the concept of benthic oxidant demand}

Benthic organic matter microbial oxidation is the basic process by which oxidants such as oxygen, nitrate and sulphate are consumed in sediments, while ammonium and phosphate are released. The organic matter content of the upper layers of sediments is therefore a logical proxy for the intensity of benthic processes. Most of the organic matter pool of sediments is, however, of very low biodegradability so that a similar total content of organic matter between two sediment samples may mask large differences in rapidly biodegradable organic matter fractions, hence in overall reactivity.

\section{Methods}

Benthic organic matter reactivity can be better characterized by measuring the associated oxygen consumption rate over a short period of time in a sediment slurry under oxic conditions (potential oxygen consumption) or by measuring nitrate consumption under anoxic conditions with added nitrate at a saturating concentration (potential denitrification rate) (Garnier et al., 2010). In the latter case, the measured rate corresponds to the oxidant demand of the organic matter degradation by the 
denitrifying microbial population present. In the former case, the measured oxygen consumption rate corresponds to the sum of the oxidant demand of the organic carbon biodegradable by the aerobic heterotrophic microbial community present and of the nitrification rate of the simultaneously released ammonium. By following in parallel the nitrate production rate, both the carbon and the nitrogen oxidant demand can be estimated (Fig. 2(a)).

Such measurements were carried out with 25 sediment samples collected in different stream-order rivers of the Seine drainage network, both upstream and downstream from the Paris urban agglomeration. Integration of the time variation curve of oxygen consumption, the denitrification rate under anoxic conditions and the ammonium production rate made it possible to determine the total oxidant demand under oxic and anoxic conditions as well as the total biodegradable organic $\mathrm{C}$ and $\mathrm{N}$ initially present in the sample.

\section{Results}

Total biodegradable organic $\mathrm{N}$ was found to be closely related to biodegradable organic C (Fig. 2(b)), as was the instant ammonification rate (not shown). Another remarkable result of these measurements is that the total $\mathrm{C}$ oxidant demand is similarly related to biodegradable organic $\mathrm{C}$ in oxic and anoxic conditions (Fig. 2(c)). This supports the view that intrinsic organic carbon degradability controls both aerobic respiration and heterotrophic denitrification by adapted communities of heterotrophic microorganisms. The data are consistent with the view that benthic organic material comprises three classes of biodegradability, a rapidly degradable fraction (with degradation constant $k 1$ of about $0.005 \mathrm{~h}^{-1}$ at $20^{\circ} \mathrm{C}$ ), a slowly biodegradable fraction $\left(k 2=0.00025 \mathrm{~h}^{-1}\right)$ and a third fraction which can be considered refractory over a yearly time span, as was postulated by the formalism of the model proposed by Thouvenot et al. $(2007,2009)$.

\section{Thouvenot's model of nutrient water column-benthic exchanges}

The model reported by Thouvenot et al. $(2007,2009)$ considers an upper layer of freshly deposited, uncompacted material, which can be re-eroded, and is assumed to be homogeneous in terms of the distribution of particulate properties, overlaying a lower layer of consolidated, stratified sediments. Molecular diffusion prevails in the compacted lower layer, while mixing coefficient is five times higher in the upper layer. Organic matter of three classes of biodegradability is brought into the upper layer by sedimentation from the water column, mixed with inorganic particulate material, and degraded there, according to their respective first-order biodegradability rate. If not re-eroded, they are compacting into the lower layer.
The model calculates the vertical distribution of dissolved oxygen and nutrients in the two sedimentary layers, taking into account the processes of ammonification, nitrification and denitrification, adsorption of ammonium and phosphate onto particulate material, as well as the resulting fluxes of dissolved species across the water-sediment interface (Fig. 3). The basis for this calculation is the solving of the diagenetic equations for oxygen, inorganic nitrogen and phosphorus species and dissolved silica, assuming a steady-state dissolved compartment.

When implemented into a river basin model (e.g., the Riverstrahler model), the river model provides, for each river stretch at any time step, the boundary conditions to the diagenetic benthic module, namely the value of all water-quality variables in the water column and all benthic particulate variables in the upper fluid layer, including the particulate organic matter concentration of all biodegradability classes, inorganic particulate material and depth of the fluid layer. The benthic module calculates the steadystate sediment-water fluxes resulting from these varying conditions.

The model has been validated in its local version with benthic chamber measurements of nutrient fluxes and nutrient analysis in the pore water of sediment cores collected at the same sites (Thouvenot et al., 2007) and in its river network version with measurements of sediment properties along the entire river network, including biodegradable organic matter concentration in the top sediment layer, denitrification potential and benthic chamber oxygen, ammonium and nitrate flux determinations (Thouvenot et al., 2009).

\section{A re-analysis of Thouvenot's model results}

By systematically exploring the response of the model to varying values of the control variables of Thouvenot's model, we aim at providing a simpler algorithm to replace the original model, thus constructing a surrogate model (or metamodel) of the original one. This purpose is often achieved by standard multivariate blind statistical analysis of the results of a large number of runs of the model with a random choice of control variables. Tool kits for such operations are available (Gorissen et al., 2010). Following this approach, Gypens et al. (2008), following exactly the same purpose as we do in this paper, made use of MonteCarlo simulations with an analytical two-layer diagenesis model to statistically derived multiple linear equations that best describes the model results.

This kind of approach, however, generally results in losing the basic understanding of the mechanistic relationships which are at the basis of the original model. We preferred instead to analyse the results according to a conceptual interpretative framework relating the nutrient fluxes across the sediment-water interface to the depthintegrated value of certain sediment properties, such as their oxidant demand and their total ammonification rate. Doing so, we not only establish empirical relationships between nutrient fluxes and state variables calculated by 


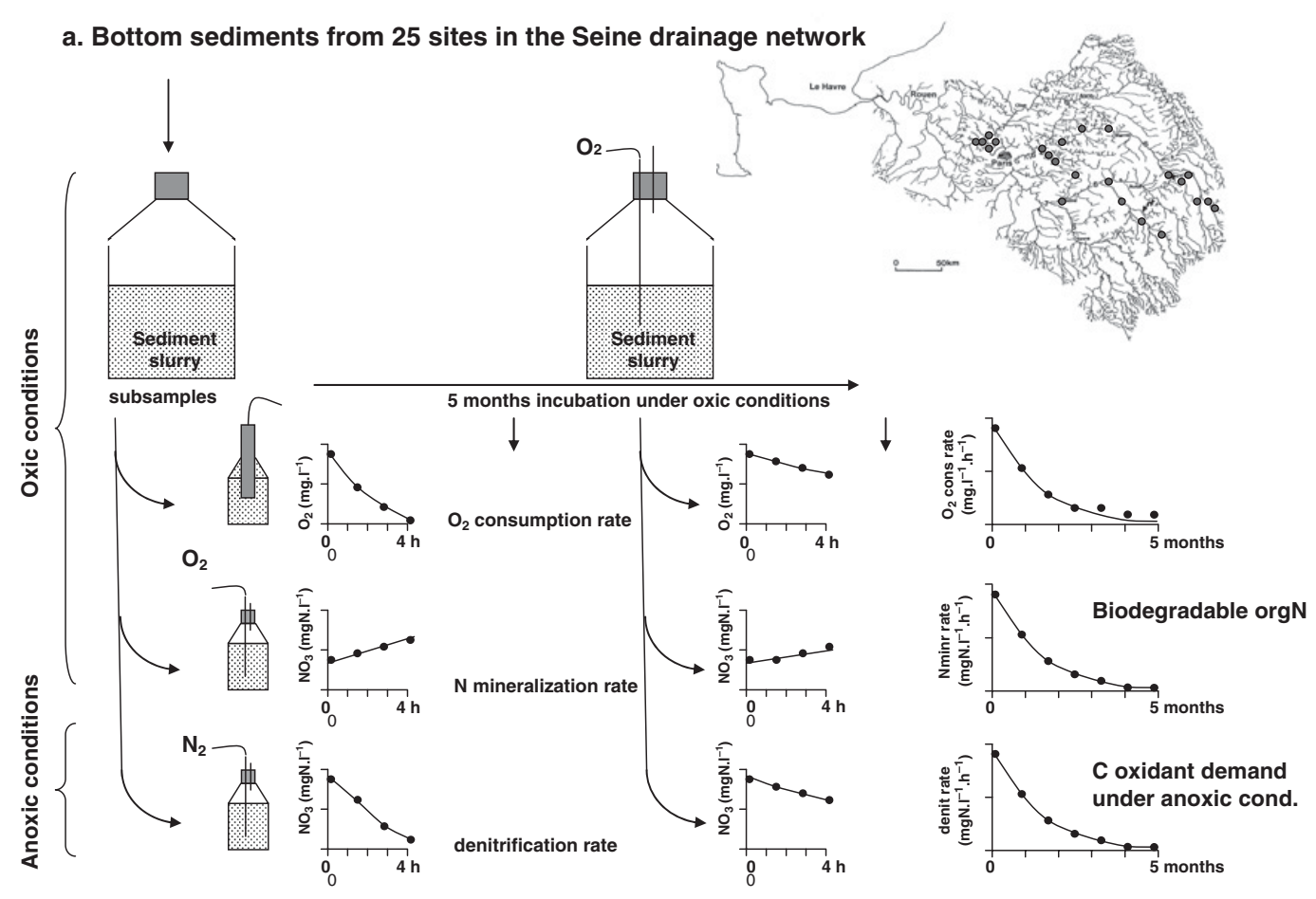

b. Rate of ammonification proportional to $\mathbf{C}$ biodegradation

c. The rate of oxidant consumption, as oxygen in

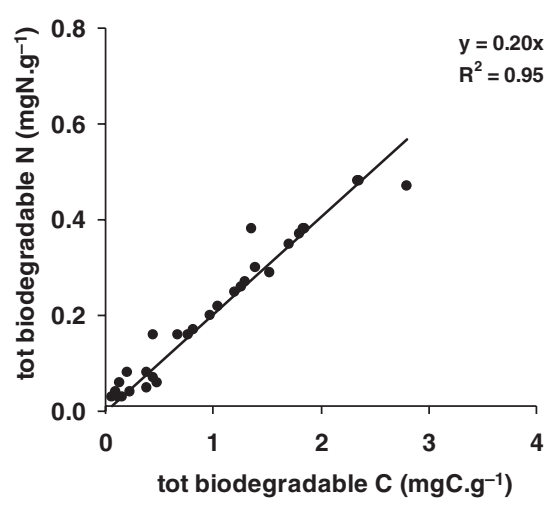
aerobiosis or as nitrate (denitrification) under anoxic conditions, is similarly related to biodegradable orgC.
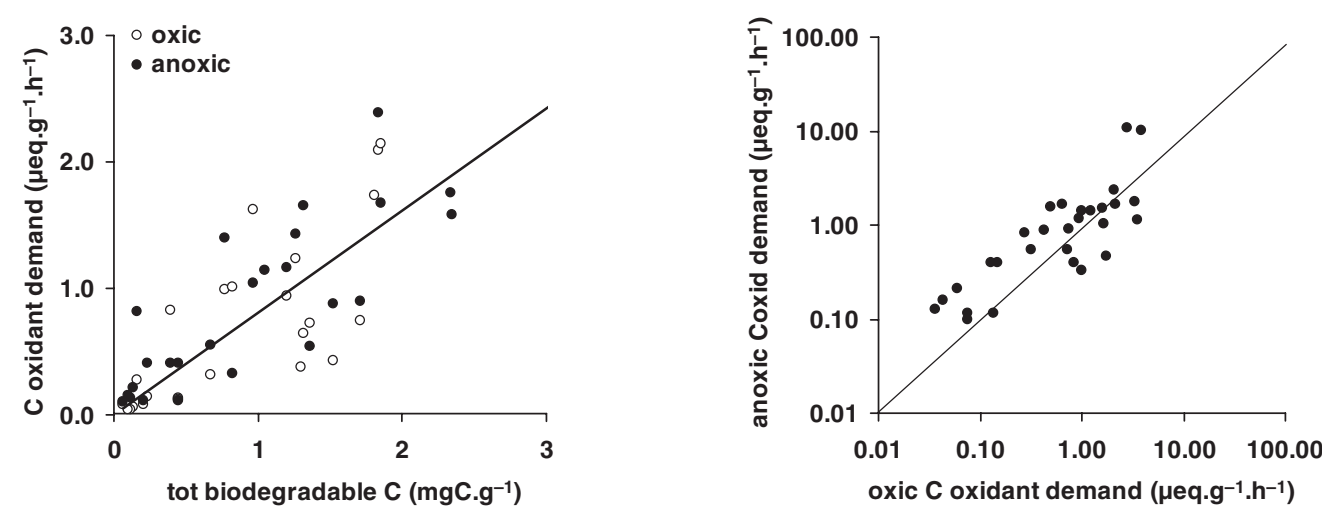

Fig. 2. (a) Experimental measurements of organic matter mineralization in sediment slurries under aerobic and anaerobic conditions. (b) Relationships between ammonification rate and organic matter degradation and between oxic and anoxic oxidant demand and biodegradable organic $\mathrm{C}$ content of sediments. 


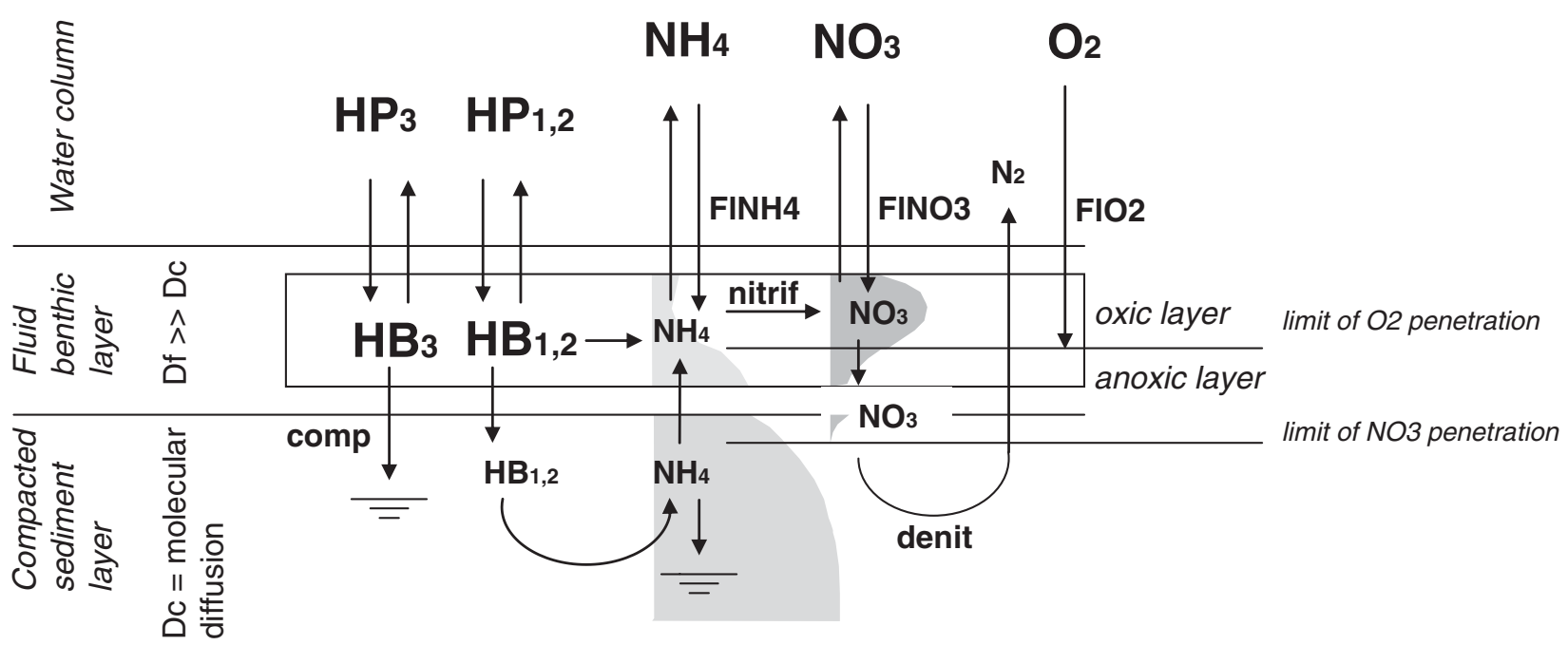

Fig. 3. State variables and processes taken into account in Thouvenot's model of benthic nutrient recycling.

the water column model, but we also provide a processbased interpretation of the model's response, which helps understand the biogeochemical behaviour of the benthic compartment.

\section{Ammonium benthic flux}

Ammonium release from the benthos can be considered a fraction of the steady-state depth-integrated ammonification rate, Ammonr. This can be expressed as the sum of the ammonification rate of the biodegradable fractions of organic matter present in the upper fluid benthic layer and of the flux of biodegradable organic nitrogen compacted into the lower sediment layer, where it will be degraded over the long run. According to the hypotheses of Thouvenot's model, this can be expressed as:

$\operatorname{Ammonr}\left(\mathrm{gN} \cdot \mathrm{m}^{-2} \cdot \mathrm{h}^{-1}\right)=1 /(c / n) *(k 1 * \mathrm{HB} 1+k 2 * \mathrm{HB} 2)$

$$
+\operatorname{comp} *(\mathrm{HB} 1+\mathrm{HB} 2) /(c / n)
$$

where HB1 is the stock of rapidly degradable benthic organic carbon (in $\mathrm{gC}^{-2}$ ); $\mathrm{HB} 2$ is the stock of slowly degradable benthic organic carbon (in $\mathrm{gC} . \mathrm{m}^{-2}$ ); $k 1$ and $k 2$ their respective first-order degradation rate $\left(\right.$ in $\left.^{-1}\right) ; c / n$ their $C: N$ ratio; comp is the compaction rate of the upper sediment layer $\left(\right.$ in $^{-1}$ ), which is considered constant at a high depth of the upper sediment layer, but tends toward zero for the thin upper sediment layer:

$$
\begin{array}{r}
\operatorname{comp}=\operatorname{compmax} *\left(\mathrm{SED}-\mathrm{SED}^{\circ}\right) / \mathrm{SED}, \\
\text { with } \quad \operatorname{comp}=0 \text { if } \mathrm{SED}<\mathrm{SED}^{\circ}
\end{array}
$$

where SED is the deposited material (in g. $\mathrm{m}^{-2}$ ); $\mathrm{SED}^{\circ}$ a threshold sediment stock set at 500 g.m ${ }^{-2}$; compmax $=0.0005 \mathrm{~h}^{-1}$.

At zero ammonium concentration in the overlaying water and no nitrification (zero oxygen in the water column), most of Ammonr is actually released to the

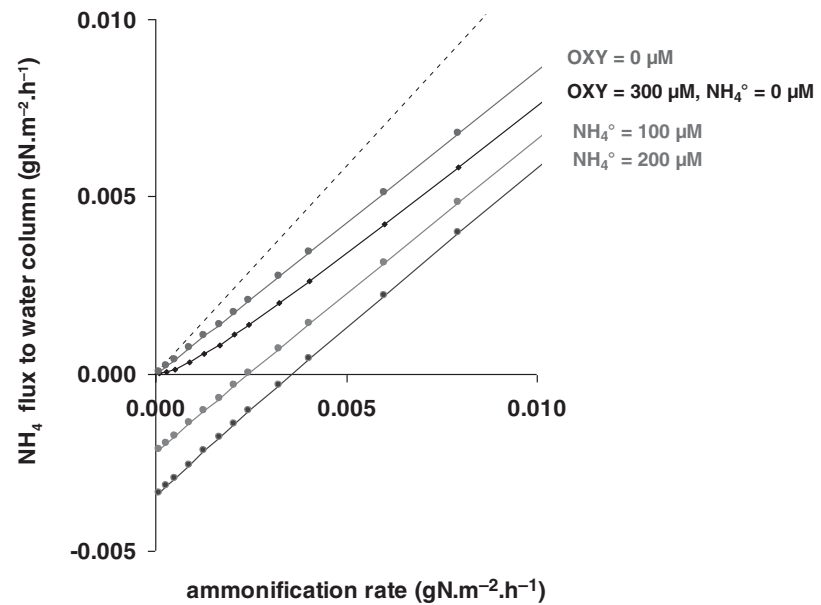

Fig. 4. Model of calculated flux of ammonium across the water sediment interface plotted against the total depth-integrated ammonification rate in sediments, for different oxygen and ammonium concentrations in the overlaying water column.

water column, with only a small fraction "buried" in the aggrading lower layer of the sediments. If oxygen is present in the water column, nitrification in the uppermost oxygenated layer of the sediment oxidizes a significant fraction of the ammonium flux (Fig. 4). At high concentrations of ammonium in the overlaying water, nitrification is enhanced by this additional source of substrate, which may lead to an inversion of the ammonium flux, migrating from the water column to the sediment at low Ammonr (Fig. 4).

The following empirical relationship quantitatively summarizes the model's results:

$$
\begin{aligned}
\mathrm{FlxNH}_{4}\left(\mathrm{gN} \cdot \mathrm{m}^{-2} \cdot \mathrm{h}^{-1}\right)= & -f_{\mathrm{NH}_{4}} * \text { Ammonr } \\
& +F_{\text {NITendo }}+F_{\text {NITexo }}
\end{aligned}
$$

The first term refers to the unburied fraction of $\mathrm{NH}_{4}$ produced by organic matter mineralization, the second to 


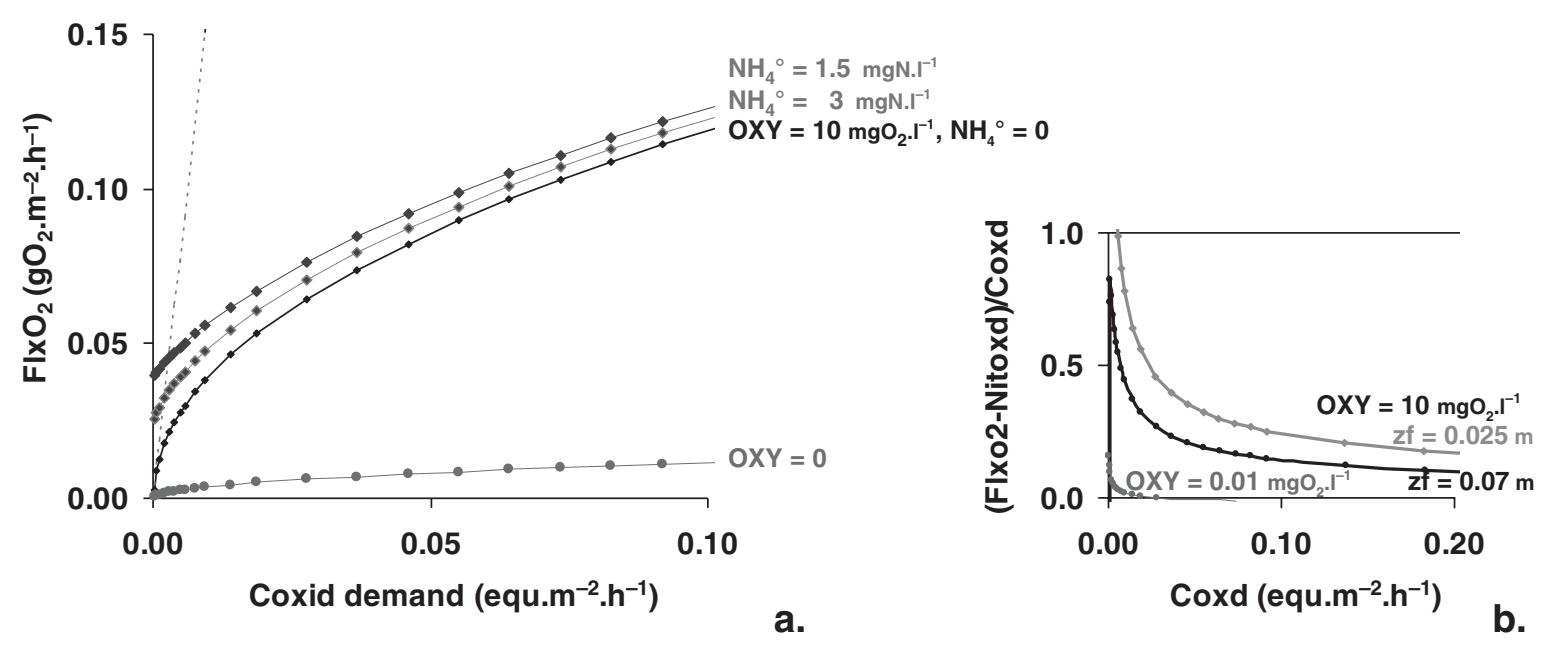

Fig. 5. Model-calculated flux of oxygen across the water-sediment interface plotted against the depth-integrated carbon oxidant demand of organic matter degradation (Coxd) in sediments, for different oxygen concentrations in the overlaying water column.

endogenic nitrification and the third to exogenic nitrification with

$$
\begin{aligned}
& f_{\mathrm{NH}_{4}}=\left(0.9-140 * z f^{3}\right) \\
& F_{\mathrm{NITendo}}\left(\mathrm{gN} \cdot \mathrm{m}^{-2} \cdot \mathrm{h}^{-1}\right)=0.015 * z f * \mathrm{OXY}^{\circ} / \mathrm{OXYsat} * \mathrm{ftemp} \\
& F_{\mathrm{NITexo}}\left(\mathrm{gN} \cdot \mathrm{m}^{-2} \cdot \mathrm{h}^{-1}\right)=0.00125 * \mathrm{NH}_{4}^{\circ} * z f /(z f+0.002 \mathrm{~m}) \\
& \quad * \mathrm{OXY} / \mathrm{OXY} \text { sat } * \text { ftemp }
\end{aligned}
$$

where $z f$ is the depth of the upper fluid sediment layer (in $\mathrm{m}$ ); $\mathrm{OXY}^{\circ}$ is the oxygen concentration in the water column (in $\mathrm{mgO}_{2} . \mathrm{L}^{-1}$ ); OXYsat is the oxygen concentration at saturation; $\mathrm{NH}_{4}^{\circ}$ is the ammonium concentration in the water column (in $\mathrm{mgN} . \mathrm{L}^{-1}$ ); ftemp is the temperature function of benthic biological processes, assumed to follow a sigmoid relationship such as $\mathrm{ftemp}=$ $\exp \left[-(t-\text { topt })^{2} / \mathrm{dti}^{2}\right]$; with topt $=20^{\circ} \mathrm{C}$ and $\mathrm{dti}=17^{\circ} \mathrm{C}$.

\section{Fluxes of oxygen across the water-sediment interface}

According to the model's hypothesis, oxygen uptake in sediments is the sum of a fraction of the oxidant demand of biodegradable organic carbon integrated over the sedimentary column and of the oxygen consumption by nitrification. The integrated carbon oxidant demand of organic matter degradation (Coxd) can be expressed as:

$$
\begin{aligned}
& \operatorname{Coxd}\left(\text { equ. } \mathrm{m}^{-2} \cdot \mathrm{h}^{-1}\right)=4 / 12 *[(k 1 * \mathrm{HB} 1+k 2 * \mathrm{HB} 2) \\
& +\operatorname{comp} *(\mathrm{HB} 1+\mathrm{HB} 2)]
\end{aligned}
$$

where $4 / 12$ is the stoichiometric coefficient from $\mathrm{gC}$ to equivalent; $\mathrm{HB} 1$ is the stock of rapidly degradable benthic organic carbon (in $\mathrm{gC}^{-2} \mathrm{~m}^{2}$ ); HB2 is the stock of slowly degradable benthic organic carbon (in $\left.\mathrm{gC}^{-2} \mathrm{~m}^{-2}\right), k 1$ and $k 2$ their respective first-order degradation rate $\left(\mathrm{in} \mathrm{h}^{-1}\right)$; comp is the compaction rate of the upper sediment layer (in $\mathrm{h}^{-1}$ ) as defined above.
The oxygen consumption linked to nitrification (Nitoxd) comprises two components, as discussed above: one related to endogenous ammonium oxidation and the other related to exogenous ammonium when the ammonium concentration in the water column is significant. Nitoxd can thus be easily calculated from fluxes already evaluated for calculating the ammonium fluxes:

$$
\operatorname{Nitoxd}\left(\text { equ.m }{ }^{-2} \cdot \mathrm{h}^{-1}\right)=8 / 14 *\left[F_{\text {NITendo }}+F_{\text {NITexo }}\right]
$$

where $8 / 14$ is the stoichiometric coefficient from $\mathrm{gN}$ to equivalent.

The flux of oxygen across the water-sediment interface $\left(\mathrm{FlxO}_{2}\right.$, in $\left.\mathrm{gO}_{2} \cdot \mathrm{m}^{-2} \cdot \mathrm{h}^{-1}\right)$ is calculated as

$$
\mathrm{FlxO}_{2}=32 / 4 *\left[f_{\text {oXY }} * \text { Coxd }+ \text { Nitoxd }\right]
$$

where $32 / 4$ is the stoichiometric coefficient from equivalent to $\mathrm{gO}_{2} ; f_{\text {OXY }}$ is the fraction of $\mathrm{C}$ oxidant demand (Coxd) which can actually be met by aerobic respiration; and the remaining fraction being met by anaerobic respiration, such as denitrification, sulphate reduction or methanogenesis.

$f_{\text {OXY }}$ decreases with increasing Coxd; it also depends on the depth (zf, m) of the upper well-mixed layer of sediment, as well as on the dissolved oxygen content of the overlaying water $\left(\mathrm{OXY} \mathrm{Y}^{\circ}\right)$ because both factors favour aerobic respiration with respect to anaerobic processes (Fig. 5). The following hyperbolic expression has been empirically found to satisfactorily account for the model's results:

$$
f_{\text {OXY }}=1-\operatorname{Coxd} /\left[\operatorname{Coxd}+0.00075 *\left(\mathrm{OXY}^{\circ} / \mathrm{OXY} \text { sat }\right) / z f\right]
$$

\section{Nitrate fluxes across the water sediment interface}

The nitrate flux across the sediment-water interface $\left(\mathrm{FlxNO}_{3}\right.$, in $\left.\mathrm{gN} \cdot \mathrm{m}^{-2} \cdot \mathrm{h}^{-1}\right)$ is the resultant of two components with opposite signs, respectively, related to denitrification and the nitrification processes.

Denitrification, like aerobic respiration, is considered to be driven by the Coxidant demand (Coxd) as defined in 

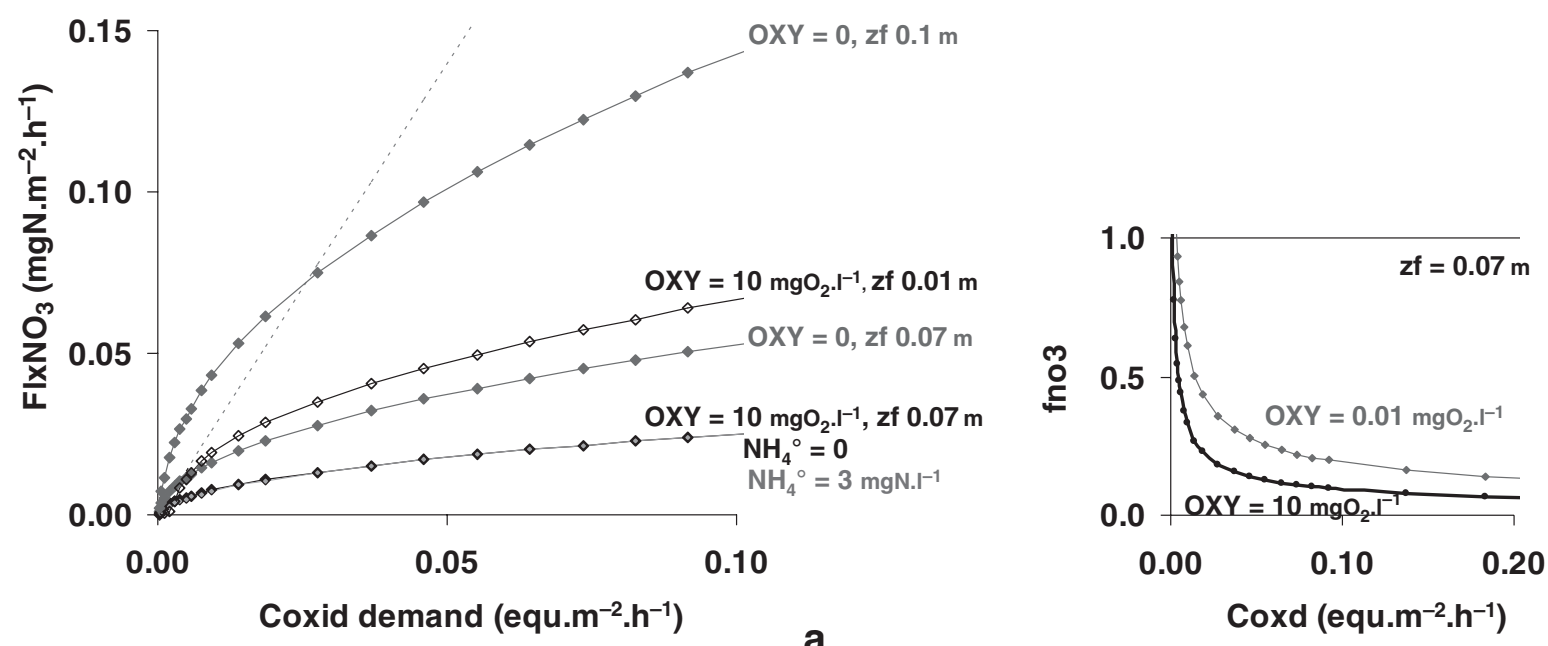

Fig. 6. Model-calculated flux of nitrate across the water-sediment interface plotted against the depth integrated carbon oxidant demand of organic matter degradation (Coxd) in sediments, for different nitrate and oxygen concentrations in the overlaying water column.

section "Fluxes of oxygen across the water-sediment interface" above. Nitrification, as also discussed in section "Ammonium benthic flux", is made up of two fractions corresponding to exogenous ammonium diffusing from the overlaying water column and to endogenous ammonium produced through organic matter mineralization. The nitrate flux can therefore be written:

$$
\mathrm{FlxNO}_{3}=14 / 5 f_{\mathrm{NO}_{3}} * \mathrm{Coxd}-F_{\mathrm{NITendo}}-F_{\mathrm{NITexo}}
$$

where $14 / 5$ is the stoichiometric coefficient from equivalent to $\mathrm{gN}-\mathrm{NO}_{3} ; f_{\mathrm{NO}_{3}}$ is the fraction of $\mathrm{C}$ oxidant demand (Coxd) met by denitrification; $f_{\mathrm{NO}_{3}}$ is a decreasing function of Coxd and an increasing function of zf (Fig. 6(a)) as well as of the nitrate concentration in the overlaying water column $\left(\mathrm{NO}_{3}{ }^{\circ}\right)$. The molar ratio between $\mathrm{NO}_{3}{ }^{\circ}$ and $\mathrm{OXY}^{\circ}$ appears to be key for the allocation of Coxd to either aerobic respiration or denitrification (Fig. 6(b)). The following empirical relationship has been found to fit the model's results:

$$
f_{\mathrm{NO}_{3}}=a\left[1-\operatorname{Coxd}^{0.7} /\left(\operatorname{Coxd}^{0.7}+c^{0.7}\right)\right] \quad(\text { dimensionless })
$$

with

$$
a=2 *\left(\mathrm{NO}_{3}^{\circ} \mathrm{m} / \mathrm{OXY}^{\circ} \mathrm{m}\right) /\left[\left(\mathrm{NO}_{3}^{\circ} \mathrm{m} / \mathrm{OXY}^{\circ} \mathrm{m}\right)+1.8\right]
$$

(dimensionless)

$$
c=\mathrm{NO}_{3}^{\circ} / 14 *[1-z f /(z f+0.0005)]\left(\text { equ. }^{-2} \cdot \mathrm{h}^{-1}\right)
$$

where $\left(\mathrm{NO}_{3}{ }^{\circ} \mathrm{m} / \mathrm{OXY}^{\circ} \mathrm{m}\right)$ is the molar ratio between nitrate and oxygen concentration in the overlaying water, while $\mathrm{NO}_{3}{ }^{\circ}$ is the nitrate concentration expressed in $\mathrm{mgN} . \mathrm{L}^{-1}$.

\section{Flux of ortho-phosphate across the water-sediment interface}

In the same way as for ammonium, the flux of orthophosphate $\left(\mathrm{PO}_{4}\right)$ released by the benthos compartment is driven by the depth-integrated organic phosphorus mineralization rate (Pminr, in gP. $\left.\mathrm{m}^{-2} \cdot \mathrm{h}^{-1}\right)$ ) in the upper fluid layer and in the compacted lower layer.

$$
\begin{aligned}
\text { Pminr }= & 1 /(c / p) *[(k 1 * \mathrm{HB} 1+k 2 * \mathrm{HB} 2) \\
& +\operatorname{comp} /(c / p) *(\mathrm{HB} 1+\mathrm{HB} 2)]
\end{aligned}
$$

where $\mathrm{HB} 1$ is the stock of rapidly degradable benthic organic carbon (in $\mathrm{gC}^{-2} \mathrm{~m}^{-2}$; $\mathrm{HB} 2$ is the stock of slowly degradable benthic organic carbon (in $\mathrm{gC} . \mathrm{m}^{-2}$ ); $k 1$ and $k 2$ the respective first-order organic matter mineralization rate (in $\mathrm{h}^{-1}$ ); $c / p$ their $\mathrm{C}: \mathrm{P}$ ratio; comp is the compaction rate of the upper sediment layer $\left(\mathrm{in} \mathrm{h}^{-1}\right.$ ).

Logically, the phosphate flux across the water sediment interface is equal to Pminr at a low upper sediment layer depth when the compaction rate is low. As the depth of the upper sediment layer increases, adsorption of orthophosphate on the inorganic fraction of the sediments, compaction of the fluid layer and the resulting burial of inorganic material result in the benthic retention of an increasingly large Pminr fraction (Fig. 7).

The following relationship describes this behaviour.

$$
\mathrm{FlxPO}_{4}\left(\mathrm{gP} \cdot \mathrm{m}^{-2} \cdot \mathrm{h}^{-1}\right)=-f_{\mathrm{PO}_{4}} \mathrm{Pminr}
$$

with

$f_{\mathrm{PO}_{4}}=1-\left[z f^{2.5} /\left(z f^{2.5}+0.032^{2.5}\right)\right] \quad$ (dimensionless)

\section{Flux of silica across the water-sediment interface}

The flux of dissolved silica is driven by the maximum dissolution rate of biogenic amorphous silica present in the two benthic layers (Sidissr, gSi.m ${ }^{-2} \cdot h^{-1}$ ), which can be expressed as

$$
\text { Sidissr }=\mathrm{kbSi} . \mathrm{BBSi}+\text { comp.BBSi }
$$

where BBSi is the pool of biogenic amorphous silica in the upper sediment layer (in gSi.m ${ }^{-2}$ ); and $\mathrm{kbSi}$ is the 

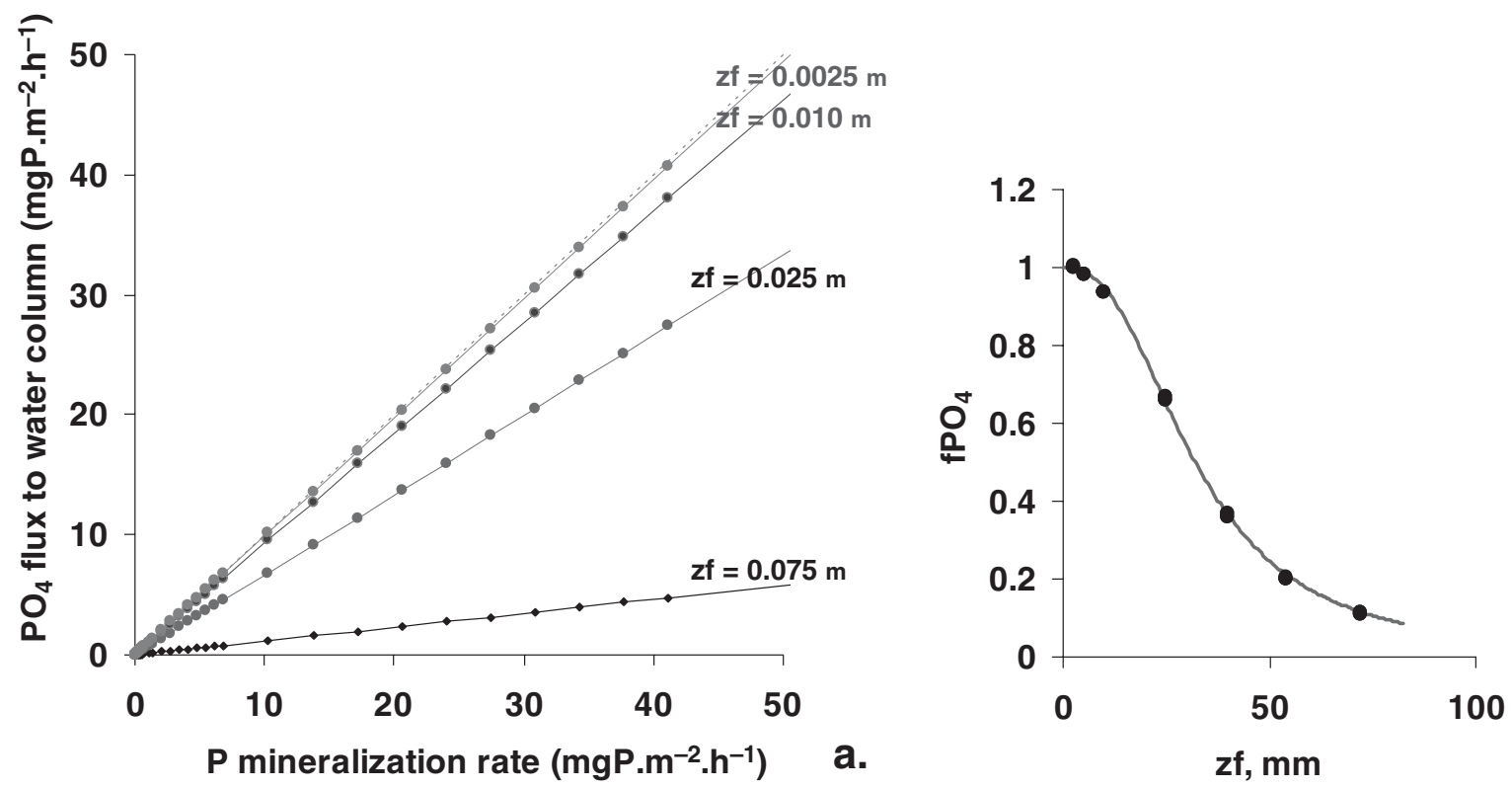

Fig. 7. (a) Model-calculated flux of phosphate across the water-sediment interface plotted against the depth-integrated $P$ mineralization rate in the sediments, for different depths of the fluid upper layer. (b) Ratio of released P flux versus P mineralization rate.
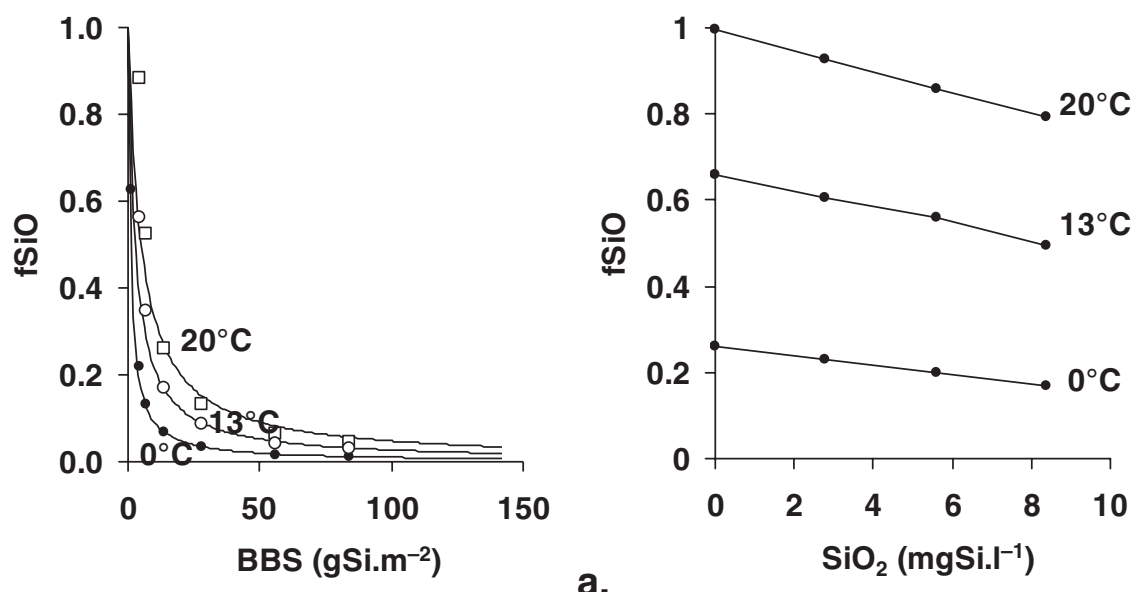

b.

Fig. 8. (a) Ratio of the model-calculated flux of silica across the water-sediment interface over the total depth-integrated maximum biogenic silica dissolution rate, at zero DSi concentration in the overlaying water. (b) Effect of dissolved silica in the overlaying water on this ratio.

temperature-dependent dissolution rate of amorphous silica $\left(\mathrm{h}^{-1}\right)$.

The two terms of equation (13) refer to the maximum dissolution in the upper fluid layer and in the compacted layer, respectively, when the pore water-dissolved silica concentration is far from the saturation concentration. The actual dissolution rate is in fact limited by the difference between the pore water-dissolved silica concentration and the saturation concentration: amorphous biogenic silica will be "fossilized" once the saturation concentration is reached in the pore water.

Accordingly, Thouvenot's model predicts a dissolved silica flux equal to a fraction of Sidissr, nearly independent on zf, but increasing strongly as temperature rises and decreasing as the pool of biogenic silica increases (Fig. 8(a)). It also decreases as the dissolved silica concentration increases in the overlaying water (Fig. 8(b)).

The following empirical relationship allows calculating the dissolved silica flux from the biogenic amorphous silica pool in the upper sediment layer.

$$
\mathrm{FlxSi}=-f_{\mathrm{SiO}} . \text { Sidissr }
$$

with

$$
\begin{aligned}
f_{\mathrm{SiO}}= & {\left[1-\mathrm{BBSi} /\left(\mathrm{BBSi}+\exp \left(0.08 \mathrm{t}^{\circ} \mathrm{C}\right)\right)\right] } \\
& -\left(0.3+0.02 \mathrm{t}^{\circ} \mathrm{C}\right) * \mathrm{SiO}^{\circ} / 28 \quad(\text { dimensionleless })
\end{aligned}
$$

where $\mathrm{t}^{\circ} \mathrm{C}$ is the water temperature, in ${ }^{\circ} \mathrm{C}$; and $\mathrm{SiO}^{\circ}$ the silica concentration in the overlaying water in $\mathrm{mgSi} . \mathrm{L}^{-1}$. 
Table 1. Comparison of the results of Thouvenot's original model with the simplified algorithm proposed in this paper, when applied to the entire Seine drainage network (420 stations over an annual cycle, i.e., 15120 pairs of results).

\begin{tabular}{llcc}
\hline & $y=a . x$ & $r^{2}$ & cv (RMSE) \\
\hline FlxNH $_{4}$ & $y=0.92 x$ & 0.76 & 0.37 \\
llxO $_{2}$ & $y=0.86 x$ & 0.76 & 0.25 \\
FlxNO $_{3}$ & $y=0.96 x$ & 0.78 & 0.25 \\
FlxPO $_{4}$ & $y=0.96 x$ & 0.85 & 0.30 \\
FlxSiO $_{2}$ & $y=1.0 x$ & 0.96 & 0.20 \\
\hline
\end{tabular}

\section{Conclusion}

Together, relations (1) to (14) above make it possible to calculate the fluxes of dissolved nutrients and oxygen across the water-sediment interface as stated in detail in the Appendix, provided the concentration of these nutrients in the water column, as well as a number of properties of the upper fluid layer of the sediment, are given by the water column model.

The validity of this new algorithm with respect to the original equations of Thouvenot et al. (2007) has been checked on the basis of the results of a run of the Seneque/ Riverstrahler model on the entire drainage network of the Seine River (see Thouvenot et al., 2009) providing the comparison of more than 15000 different situations. The two calculation procedures agree satisfactorily (Table 1).

The proposed new algorithm will replace the original equations in the future versions of the Riverstrahler model, because it requires much less calculation time and is numerically much more stable. It also constitutes in itself a generic module for calculating benthic fluxes that can be implemented into any other model of nutrient dynamics in lentic or lotic ecosystems.

Acknowledgements. This work is part of the EMoSEM Project (SeasERA, EUFP7ER-NET) coordinated by Geneviève Lacroix, MUMM (Belgium) and funded in France by the Agence Nationale de la Recherche (ANR).

\section{References}

Aller R.C. and Aller J.Y., 1992. Meiofauna and solute transport in marine muds. Limnol. Oceanogr., 37, 1018-1033.

Arndt S., Jørgensen B.B., LaRowe D.E., Middelburg J.J., Pancost R.D. and Regnier P., 2013. Quantifying the degradation of organic matter in marine sediments: a review and synthesis. Earth-Sci. Rev., 123, 53-86.

Arnold J.G., Srinivasan R., Muttiah R.S. and Williams J.R., 1998. Large area hydrologic modeling and assessment part I: model development. J. Am. Water Resour. Assoc., $34,73-89$.

Arnold J.G., Srinivasan R., Muttiah R.S., Allen P.M. and Walker C., 1999. Continental scale simulation of the hydrologic balance. J. Am. Water Resour. Assoc., 35, 1037-1052.

Berner R.A., 1980. Early Diagenesis: a Theoretical Approach, Princeton University Press, Princeton, NJ.
Billen G. and Lancelot C., 1988. Modelling benthic nitrogen cycling in temperate coastal ecosystems. In: Blackburn T.H. and Sørensen J. (eds.), Nitrogen Cycling in Coastal Marine Environments, John Wiley \& Sons Ltd., London, 342-378.

Billen G., Dessery S., Lancelot C. and Meybeck M., 1989. Seasonal and inter-annual variations of nitrogen diagenesis in the sediments of a recently impounded basin. Biogeochemistry, 8, 73-100.

Boudreau B.P., 1996. A method-of-lines code for carbon and nutrient diagenesis in aquatic sediments. Comput. Geosci., 22, 479-496.

Boudreau B.P., 1997. Diagenetic Models and their Implementation, Springer-Verlag, Berlin Heidelberg.

Dedieu K., Rabouille C., Thouzeau G., Jean F., Chauvaud L., Clavier J., Mesnage V. and Ogier S., 2007. Benthic O2 distribution and dynamics in a Mediterranean lagoon (Thau, France): an in situ microelectrode study. Estuar. Coast. Shelf Sci., 72, 393-405.

Even S., Billen G., Bacq N., Théry S., Ruelland D., Garnier J., Cugier P., Poulin M., Blanc S., Lamy F. and Paffoni C., 2007. New tools for modelling water quality of hydrosystems: an application in the Seine River basin in the frame of the Water Framework Directive. Sci. Total Environ., 375, 274-291.

Flipo N., Even S., Poulin M., Tusseau-Vuillemin M.-H., Ameziane T. and Dauta A., 2004. Biogeochemical modelling at the river scale: plankton and periphyton dynamics - Grand Morin case study, France. Ecol. Model., 176, 333-347.

Garban B., Ollivon D., Poulin M., Gaultier V. and Chesterikoff A., 1995. Exchanges at the sediment-water interface in the river Seine, downstream from Paris. Water Res., 29, 473-481.

Garnier J. and Billen G., 1993. Ecological interactions in a shallow sand-pit lake (Créteil Lake, France). A modelling approach. Hydrobiologia, 275/276, 97-114.

Garnier J., Mounier M., Laverman A. and Billen G., 2010. Potential denitrification and nitrous oxide production in the sediments of the Seine River Drainage Network (France). J. Environ. Qual., 39, 449-459.

Gorissen D., Crombecq K., Couckuyt I., Dhaene T. and Demeester P., 2010. A surrogate modeling and adaptive sampling toolbox for computer based design. J. Mach. Learn. Res., 11, 2051-2055.

Gypens N., Lancelot C. and Soetaert K., 2008. Simple parameterisations for describing $\mathrm{N}$ and $\mathrm{P}$ diagenetic processes: application in the North Sea. Prog. Oceanogr., 76, 89-110.

Lerman A., 1978. Chemical exchange across sediment-water interface. Ann. Rev. Earth Planet. Sci., 6, 281-303.

Lorke A. and MacIntyre S., 2009. The Benthic Boundary Layer in Rivers, Lakes, and Reservoirs. In: Likens G.E. (ed.), Encyclopedia of Inland Waters, Elsevier/Academic Press, Oxford, UK, 505-514.

Peyrard D., Delmotte S., Sauvage S., Namour P., Gerino M., Vervier P. and Sanchez-Perez J.M., 2011. Longitudinal transformation of nitrogen and carbon in the hyporheic zone of an N-rich stream: a combined modelling and field study. Phys. Chem. Earth, 36, 599-611.

Rabouille C. and Gaillard J.-F., 1991. Towards the EDGE: early diagenetic global explanation. A model depicting the early diagenesis of organic matter, $\mathrm{O}_{2}, \mathrm{NO}_{3}, \mathrm{Mn}$ and $\mathrm{PO}_{4}$. Geochim. Cosmochim. Acta, 55, 2511-2525. 
Ruelland D., Billen G., Brunstein D. and Garnier J., 2007. SENEQUE: a multi-scaled GIS interface to the RIVERSTRAHLER model of the biogeochemical functioning of river systems. Sci. Total Environ., 375, 257-273.

Runkel R.L., McKnight D.M. and Rajaram H., 2003. Modeling hyporheic zone processes. Adv. Water Resour., 26, 901-905.

Sánchez-Pérez J.M., Vervier P., Garabétian F., Sauvage S., Loubet S., Rols J.L., Bariac T. and Weng P., 2003. Nitrogen dynamics in the shallow groundwater of a riparian wetland zone of the Garonne, SW France: nitrate inputs, bacterial densities, organic matter supply and denitrification measurements. Hydrol. Earth Syst. Sci. Discuss., 7, 97-107.

Seitzinger S.P., Styles R.V., Boyer E.W., Alexander R.B., Billen G., Howarth R.W., Mayer B. and Van Breemen N., 2002. Nitrogen retention in rivers: model development and application to watersheds in the northeastern U.S.A. Biogeochemistry, 57/58, 199-237.

Sheibley R.W., Jackman A.P., Duff J.H. and Triska F.J., 2003. Numerical modeling of coupled nitrification-denitrification in sediment perfusion cores from the hyporheic zone of the Shingobee River, MN. Adv. Water Resour., 26, 977-987.

Soetaert K., Herman P.M.J. and Middelburg J.J., 1996. A model of early diagenetic processes from the shelf to abyssal depths. Geochim. Cosmochim. Acta, 60, 1019-1040.

Soetaert K., Middelburg J.J., Herman P.M.J. and Buis K., 2000. On the coupling of benthic and pelagic biogeochemical models. Earth-Sci. Rev., 51, 173-201.

Testa J.M., Brady D.C., Di Toro D.M., Boynton W.R., Cornwell J.C. and Kemp W.M., 2013. Sediment flux modeling: simulating nitrogen, phosphorus, and silica cycles. Estuarine Coast. Shelf Sci., 131, 245-263.

Thieu V., Billen G. and Garnier J., 2009. Nutrient transfer in three contrasting NW European watersheds: The Seine, Somme, and Scheldt Rivers. A comparative application of the Seneque/Riverstrahler model. Water Res., 43, 1740-1748.

Thouvenot M., Billen G. and Garnier J., 2007. Modelling nutrient exchange at the sediment - water interface of River Systems. J. Hydrol., 341, 55-78.

Thouvenot-Korppoo M., Billen G. and Garnier J., 2009. Modelling benthic denitrification processes over a whole drainage network. J. Hydrol., 379, 239-250.

Vanderborght J.-P., Wollast R. and Billen G., 1977. Kinetic models of diagenesis in disturbed sediments. Part I: mass transfer properties and silica diagenesis. Limnol. Oceanogr., 22, 787-793.

Viollier E., Rabouille C., Apitz S.E., Breuer E., Chaillou G., Dedieu K., Furukawa Y., Grenz C., Hall P., Janssen J., Morford J.L., Poggiale J.-C., Roberts S., Shimmield T., Taillefer M., Tengberg A., Wenzhöfer F. and Witte U., 2003. Benthic biogeochemistry: state of the art technologies and guidelines for the future of in situ survey. J. Exp. Mar. Biol. Ecol., 285-286, 5-31.

Weng P., Sánchez-Pérez J.M., Sauvage S., Vervier P. and Giraud F., 2003. Assessment of the quantitative and qualitative buffer function of an alluvial wetland: hydrological modelling of a large floodplain (Garonne River, France). Hydrol. Process., 17, 2375-2392.

Westrich J.T. and Berner R.A., 1984. The role of sedimentary organic matter in bacterial sulfate reduction: the -model tested. Limnol. Oceanogr., 29, 236-249. 


\section{Appendix}

Variables to be calculated by the main water column model: In the water column:

temp: temperature $\left({ }^{\circ} \mathrm{C}\right)$

$\mathrm{OXY}^{\circ}$ : oxygen concentration $\left(\mathrm{mgO}_{2} \cdot \mathrm{L}^{-1}\right)$

$\mathrm{NO}_{3}^{\circ}$ : nitrate concentration $\left(\mathrm{mgN} \cdot \mathrm{L}^{-1}\right)$

$\mathrm{NH}_{4}^{\circ}$ : ammonium concentration (mgN.L ${ }^{-1}$ )

$\mathrm{PO}_{4}{ }^{\circ}$ : ortho-phosphate concentration (mgP.L ${ }^{-1}$ )

$\mathrm{SiO}^{\circ}$ : dissolved silica concentration $\left(\mathrm{mgSi} . \mathrm{L}^{-1}\right)$

\section{In the upper fluid sediment layer:}

SED: stock of inorganic material deposited (g.m $\left.{ }^{-2}\right)$

HB1: stock of rapidly biodegradable organic carbon $\left(\mathrm{gC} . \mathrm{m}^{-2}\right)$

HB2: stock of slowly biodegradable organic carbon $\left(\mathrm{gC} . \mathrm{m}^{-2}\right)$

BBSi: stock of particulate biogenic amorphous silica $\left(\mathrm{gSi} . \mathrm{m}^{-2}\right)$

\section{Parameters to be defined}

$\Phi$ : porosity of the fluid sediment layer (typically 0.88 in the fluid layer);

$\delta$ : density of the sedimented material (typically $2.310^{6} \mathrm{~g} \cdot \mathrm{m}^{-3}$ );

$k 1$ : temperature-dependent first-order degradation rate of rapidly labile organic matter $\left(\mathrm{h}^{-1}\right)$;

$k 2$ : first-order degradation rate of slowly degradable organic matter $\left(\mathrm{h}^{-1}\right)$;

kbSi: first-order dissolution rate of biogenic silica at zero dissolved silica concentration $\left(\mathrm{h}^{-1}\right)$;

$c / n$ : weight/weight $C / N$ ratio of biodegradable organic matter (typically 7);

$c / p$ : weight/weight $C / P$ ratio of biodegradable organic matter (typically 40 );

ftemp is the temperature function of benthic biological processes, assumed to follow a sigmoid relationship, such as ftemp $=\exp \left[-(t-\text { topt })^{2} / \mathrm{dti}^{2}\right]$;

with topt $=20^{\circ} \mathrm{C}$ and $\mathrm{dti}=17^{\circ} \mathrm{C}$.

Relationships to calculate the fluxes across the sedimentwater interface:

Driving variables:

$z f:$ depth of the upper fluid sediment layer (m)

$$
z f=\mathrm{SED} /[d *(1-F)]
$$

comp: compaction rate of the upper sediment layer $\left(\mathrm{h}^{-1}\right)$

$$
\begin{aligned}
& \operatorname{comp}=\operatorname{compmax} *\left(\mathrm{SED}-\mathrm{SED}^{\circ}\right) / \mathrm{SED}, \quad \text { with } \\
& \quad \operatorname{comp}=0 \text { if } \mathrm{SED}<\mathrm{SED}^{\circ}
\end{aligned}
$$

where

$\mathrm{SED}^{\circ}$ is a threshold sediment stock set at 500 g.m ${ }^{-2}$

$$
\text { compmax }=0.0005 \mathrm{~h}^{-1}
$$

Ammonr: depth-integrated ammonification rate $\left(\mathrm{gN} \cdot \mathrm{m}^{-2} \cdot \mathrm{h}^{-1}\right)$

$$
\begin{aligned}
\text { Ammonr }= & 1 /(c / n) *(k 1 * \mathrm{HB} 1+k 2 * \mathrm{HB} 2) \\
& +\operatorname{comp} *(\mathrm{HB} 1+\mathrm{HB} 2) /(c / n)
\end{aligned}
$$

Coxd: Carbon oxidant demand (equ.m ${ }^{-2} \cdot h^{-1}$ )

$$
\begin{aligned}
& \operatorname{Coxd}=4 / 12 *[(k 1 * \mathrm{HB} 1+k 2 * \mathrm{HB} 2) \\
& \quad+\operatorname{comp} *(\mathrm{HB} 1+\mathrm{HB} 2)]
\end{aligned}
$$

Pminr: depth-integrated rate of organic phosphorus mineralization $\left(\mathrm{gP} \cdot \mathrm{m}^{-2} \cdot \mathrm{h}^{-1}\right)$

Pminr $=1 /(c / p) *[(k 1 * \mathrm{HB} 1+k 2 * \mathrm{HB} 2)+\operatorname{comp} /(c / p)$

$$
*(\mathrm{HB} 1+\mathrm{HB} 2)]
$$

Sidissr: depth-integrated maximum biogenic silica dissolution rate

$$
\text { Sidissr }=\mathrm{kbSi} \text {. BBSi }+ \text { comp. BBSi }
$$

\section{Fluxes of dissolved nutrients:}

$$
\begin{aligned}
\mathrm{FlxNH}_{4}\left(\mathrm{gN} \cdot \mathrm{m}^{-2} \cdot \mathrm{h}^{-1}\right)= & -f_{\mathrm{NH}_{4}} * \text { Ammonr }+F_{\text {NITendo }} \\
& +F_{\text {NITexo }} \text { in } \mathrm{gN} \cdot \mathrm{m}^{-2} \cdot \mathrm{h}^{-1}
\end{aligned}
$$

with

$$
f_{\mathrm{NH}_{4}}=\left(0.9-140 * z f^{3}\right)
$$

$F_{\text {NITendo }}\left(\mathrm{gN} \cdot \mathrm{m}^{-2} \cdot \mathrm{h}^{-1}\right)=0.015 * z f * \mathrm{OXY}^{\circ} / \mathrm{OXY}$ sat $*$ ftemp

$F_{\text {NITexo }}\left(\mathrm{gN} \cdot \mathrm{m}^{-2} \cdot \mathrm{h}^{-1}\right)=0.00125 * \mathrm{NH}_{4}^{\circ} * z f /(z f+0.002 \mathrm{~m})$ $* \mathrm{OXY}^{\circ} / \mathrm{OXY}$ sat $*$ ftemp

$\mathrm{FlxO}_{2}=32 / 4 *\left[f_{\text {OXY }} *\right.$ Coxd + Nitoxd $]$ in $\mathrm{gO}_{2} \cdot \mathrm{m}^{-2} \cdot \mathrm{h}^{-1}$

with

$$
\begin{gathered}
\text { Nitoxd }=8 / 14 *\left[F_{\mathrm{NITendo}}+F_{\mathrm{NITexo}}\right] \text { in equ. } \mathrm{m}^{-2} \cdot \mathrm{h}^{-1} \\
f_{\mathrm{OXY}}=1-\mathrm{Coxd} /[\text { Coxd }+0.00075 \\
*(\mathrm{OXY} / \mathrm{OXY} \text { sat }) / z f] \\
\mathrm{FlxNO}_{3}=14 / 5 f_{\mathrm{NO}_{3}} * \text { Coxd }-F_{\mathrm{NITendo}} \\
\\
-F_{\mathrm{NITexo}} \text { in } \mathrm{gN} \cdot \mathrm{m}^{-2} \cdot \mathrm{h}^{-1}
\end{gathered}
$$

with

$$
\begin{gathered}
f_{\mathrm{NO}_{3}}=a\left[1-\mathrm{Coxd}^{0.7} /\left(\mathrm{Coxd}^{0.7}+c^{0.7}\right)(\text { dimensionless })\right. \\
\begin{aligned}
a= & 2 *\left(\mathrm{NO}_{3}^{\circ} \mathrm{m} / \mathrm{OXY}^{\circ} \mathrm{m}\right) /\left[\left(\mathrm{NO}_{3}^{\circ} \mathrm{m} / \mathrm{OXY}^{\circ} \mathrm{m}\right)\right. \\
& +1.8](\text { dimensionless }) \\
c= & \mathrm{NO}_{3}^{\circ} / 14 *[1-z f /(z f+0.0005)]\left(\text { equ. } \mathrm{m}^{-2} \cdot \mathrm{h}^{-1}\right) \\
& \mathrm{FlxPO}_{4}\left(\mathrm{gP} \cdot \mathrm{m}^{-2} \cdot \mathrm{h}^{-1}\right)=-f_{\mathrm{PO}_{4}} \mathrm{Pminr}
\end{aligned}
\end{gathered}
$$

with

$$
\begin{gathered}
f_{\mathrm{PO}_{4}}=1-\left[z f^{2.5} /\left(z f^{2.5}+0.032^{2.5}\right)\right](\text { dimensionless }) \\
\mathrm{FlxSi}=-f_{\mathrm{SiO}} . \text { Sidissr }
\end{gathered}
$$

with

$$
\begin{aligned}
f_{\mathrm{SiO}}= & {\left[1-\mathrm{BBSi} /\left(\mathrm{BBSi}+\exp \left(0.08 \mathrm{t}^{\circ} \mathrm{C}\right)\right)\right]-(0.3} \\
& \left.+0.02 \mathrm{t}^{\circ} \mathrm{C}\right) * \mathrm{SiO}^{\circ} / 28(\text { dimensionleless }) .
\end{aligned}
$$

